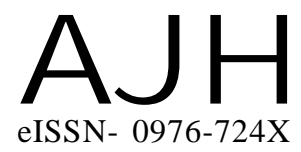

Received : 22.02.2017

Revised : 24.04.2017

Accepted : 08.05.2017

Members of the Research Forum

Associated Authors:

${ }^{1}$ Department of Horticulture, Faculty

of Agriculture, Annamalai

University, Annamalai Nagar,

CHIDAMBARAM (T.N.) INDIA

Email : kiransharaj@gmail.com

Author for correspondence :

D. ESAKKIMUTHU

Department of Horticulture, Faculty

of Agriculture, Annamalai

University, Annamalai Nagar,

CHIDAMBARAM (T.N.) INDIA

Email : mesakki50@gmail.com
THEASIAN JOURNALOF HORTICULTURE

Volume 12 | Issue 1 | June, 2017 | 55-58

Visit us -www.researchjournal.co.in

RESEARCH PAPER

DOI : 10.15740/HAS/TAJH/12.1/55-58

\title{
Studies on the effect of media on sucker production of banana cv. POOVAN
}

D. ESAKKIMUTHU AND ARUMUGAM SHAKILA ${ }^{1}$

ABSTRACT : In vivo macropropagation is an alternative simple and cheap technique for banana multiplication. The experiment was conducted in Completely Randomized Design with 13 treatments in three replications. The treatments consisted of three growing media (FYM, Rice hull, Sawdust), two biofertilizers (Azospirillum and VAM) with sand alone as control. Observations on the production of primary, secondary and tertiary buds was recorded. The results of the study revealed that use of FYM + VAM $\left(\mathrm{T}_{7}\right)$ as growing media resulted in increasing the primary, secondary and tertiary bud regeneration. The time taken for emergence of primary, secondary and tertiary buds was also earlier in the treatment $\mathrm{T}_{7}(\mathrm{FYM}+\mathrm{VAM})$.

KEY WORDS : Growing media, Suckers, Biofertilizers, Regeneration of buds

HOW TO CITE THIS ARTICLE : Esakkimuthu, D. and Shakila, Arumugam (2017). Studies on the effect of media on sucker production of banana cv. POOVAN. Asian J. Hort., 12(1) : 55-58, DOI : 10.15740/HAS/TAJH/12.1/55-58. 